\title{
The Power is in the Partnership: Families as Partners in Bilingual Bicultural Family Literacy Programs
}

\author{
Gresilda Tilley-Lubbs \\ Virginia Tech/Virginia Polytechnic Institute and State University, Blacksburg, USA. \\ Email: glubbs@vt.edu

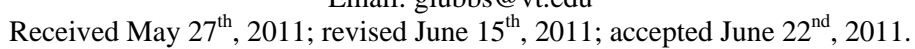

\begin{abstract}
This paper presents a research project that involved Mexican and Honduran families in a family literacy program through a service-learning course of cross-cultural education for teacher education candidates The study examined how the families in the program articulated their purposes for participating in the program and how they changed their attitudes toward education and toward the program, moving from a stance of participant to stakeholder in the program. The paper also describes the dissonance that occurred when the program incorporated an online language learning program. Despite the dissonance, however, the instructor posits that a family literacy program that regards the families as partners offers numerous possibilities for strengthening children's education.
\end{abstract}

Keywords: Service-Learning, Community-Based Education, Family Literacy, ESL/EFL

\section{Introduction}

This paper presents a research project that engaged Mexican and Honduran families in a family literacy program. The program provided bilingual bicultural educational experiences for parents and children through a service-learning course of crosscultural education for teacher candidates at a Research I university. The study examined how the families in the program articulated their purposes for participating in a family literacy program over a period of two-and-one-half years. The study also investigated the ways that the families changed their attitudes, moving from a stance of participant to stakeholder in the program. The paper also describes the dissonance that occurred when the program changed from an informal monthly gathering whose program focused on literacy to a formal computer-based program for the adults to learn English and to strengthen their literacy skills in Spanish. Despite the dissonance, however, I posit that a family literacy program that regards families as partners offers numerous possibilities for strengthening children's education.

\section{Theoretical Framework}

Crossing the Border through Service-Learning provides the context for the family literacy program. Service-learning is a form of experiential education in which students engage through the intersection of academic knowledge and community engagement interpreted through constant reflection (TilleyLubbs, 2007). It provides an opportunity for teacher candidates to put into practice the theory they study in the methods class, helping them understand the influence of language, culture, ability, family, and community on student learning and development. In addition, as teacher candidates collaborate with families in the community, they learn to understand and value the strengths and values that all students bring to school thus fostering an attitude change from regarding immigrant children from a deficit model (Nieto, 1999). Teacher education programs that strive to facilitate a concern for social justice issues (Cochran-Smith, 1999) need to encourage student teachers to be in the community so that they cease to see those from diverse backgrounds as "they". If teachers are to have knowledge of students, they must know how students develop under various conditions, understanding the influence of language, culture, ability, family, and community on student learning and development (Cochran-Smith, 1999; Freire, 1970; Greenberg \& Moll, 1990). They should have opportunities that are grounded in inquiry, experimentation, and reflection (Smylie, Bay, \& Tozer). Serving in diverse cultural settings familiarizes students with the beliefs and practices of other cultures, providing a bridge to cross from the world of the privileged university to that of the marginalized immigrant population (Ward, 1997; Wood, 1998).

Although children who are learning English as a non-heritage language may not be familiar with the language or customs of the school they enter as recent immigrants, nonetheless they bring to the school and the community rich funds of knowledge (González, Moll, \& Amanti, 2005), whether in terms of academic or practical knowledge. In order for these children to find success in school, it is necessary that they continue to feel value for the linguistic and cultural heritage that frames their lives. However they must learn English so they can succeed, not only in their English Language Learning (ELL) class, but also in their content area classes. Those children who learn English in a bilingual setting will be able to draw upon previously acquired literacy, transferring that knowledge to the acquisition of English (Krashen, 1997). Biliteracy also strengthens reading and writing in language minority students (Grant \& Wong, 2003). Likewise, drawing on the funds of knowledge in the immigrant community strengthens the bicultural biliteracy approach that complements a viable ELL program literacy (Moll \& Greenberg, 1990). 
In a service-learning experience, the needs of the community shape the project (Anderson, 1999). As parents become stakeholders and take ownership of the program, they join their children in learning to "read the word" while "reading the world" (Freire \& Macedo, 1987). Through a family literacy program, children and their parents learn how to learn; they learn how to be successful students in a new world with a different perspective on literacy. By involving immigrant parents in the education of their children, teachers are able to find community advocates for English language learning especially when the culture of the children differs significantly from that of the teacher (Gadsden, 2004). Involving parents results in conviviencia, the flowing moments of collective creation and solidarity, bonding in a joint effort (Jasis \& Ordoñez-Jasis, 2004). Social change occurs through personal transformation of worldview (Heaney, 1996).

Research indicates that language-minority parents are willing to help their children succeed academically, and that children who receive help at home are more likely to develop literacy (August \& Shanahan, 2006). Family literacy programs create a space for parents to negotiate a critical curriculum (Vasquez, 2001). Successful family literacy programs reflect input from the parents and children (Gadsden, 2004). Using Latino literature written in Spanish provides opportunities for parents to hone their means of making sense of the world through literacy; shared situational autobiography in an FLP promotes adjustment and the formation of a support system (Pierce \& Brisk, 2002). Therefore literacy for English language learners should be comprised of the valuing of their funds of knowledge and the involvement of the caregivers in the home, goals framed by family literacy programs.

\section{Methods of Inquiry and Data Sources}

The overarching objective of this study was to examine how the families described their goals for themselves and their children during a period of five semesters. I sought to investigate their changes in attitude as the participated in the program. As they stepped into leadership roles in the program, I examined the differences in their attitudes toward their children and their education. Finally, I wanted to investigate the implications for family literacy programs situated in service-learning programs.

The nature of the research necessitated the use of qualitative research methods in using ethnographic data collecting techniques to examine how the Mexican and Honduran families describe their goals and gains for themselves and their children in the Family Literacy Program. The setting of the monthly meeting presented the opportunity to observe the families as they work together and with the students in the planned activities.

Crossing the Border through Service-Learning was an academic course that partnered students with Mexican and Honduran families in the community. The students met on campus once a week to discuss academic readings. They spent 50 hours per semester with their partner family, teaching the adults English, tutoring the children, providing cultural navigation, and learning Spanish. Once a month they met with the families in the Family Literacy Program, serving as aides for the volunteer teachers who provided classes for the children. The program was grant-funded, and the grant provided books for the children and meals for the meetings.

The grant also funded Auralog, an online interactive language learning program, for the women. They did the program in English, and also in Spanish to strengthen their literacy skills in their native language. The students provided assistance with the technical aspects of Auralog. Only two of the 22 women who initially participated in the Auralog workshops had ever used a computer, so they relied on the students to answer questions as they emerged.

The adults were mostly women, partly because of the men's schedules, and partly because the men regarded it as a women's and children's program. Their ages ranged from 23 - 45, and their educational levels ranged from sixth grade through the first year of university. They also represented rural and urban backgrounds, both in Mexico and Honduras. The children ranged from under one year through eighth grade.

The classes were comprised of interactive bilingual bicultural activities for the children, with written follow-up activities provided for the parents. The parenting and support sessions for the adults were provided by a volunteer Chilean psychologist. The parents were also provided with age-appropriate follow-up interactive activities to do with their children at home.

I collected data at the beginning of the five semesters, both fall and spring, by having the women write why they stayed in the program and what their goals were for the semester. At the end of the semester they participated in a similar activity in which they wrote about the goals they had reached and differences they had observed in their children's attitudes toward or performance in school.

The first year I collected data by having families fill out baseline data sheets to collect information about literacy beliefs and reasons for participating in the program. They were also asked to fill out monthly evaluation sheets. Although the information requested was similar to what they provided in the free write activity, the women were reluctant to fill them out, saying they did not know what to write, in contrast to the free writes which resulted in rich data in the mothers' voices.

I also conducted formal interviews with the women regarding their interactions with the Family Literacy Program. The interviews were transcribed. The women participated in reading circles in which they relate assigned Latino literature to their own lives, representing the ideas of the group on butcher block paper which I collected as data. Lastly, at the end of the semester, the students and partner families produced PowerPoint presentations about their literacy experiences, which they shared with the group at the final FLP meeting; the PowerPoints also served as data.

I functioned as an observer, observer-participant, participant-observer, and participant, depending on the situation. Much of the data was collected informally in conversations with the participants in the program during the five semesters. The interviews and meetings occurred on campus, in homes, in the church where the large meetings took place, at restaurants, and on the telephone. I kept field notes for all the meetings and conversations. I sought patterns or significance through direct interpretation of the data, constantly consolidating, reducing, and interpreting them (Merriam, 1998). I present the findings in terms of emergent themes and dissonances (Lawrence-Lightfoot \& Davis, 1997). 


\section{Results of the Study}

The findings have two sections. First I consider the overall impact of the Family Literacy Program on the families who participated in the program over the five semesters. I examine the goals the women stated for their children, the changes in their attitudes, and their increased participation in the planning and implementation of the meetings.

The data demonstrated four supporting themes. First, the women described sense of empowerment from learning parenting skills. They specifically described knowing how to talk to their children about subjects such as sex, learning how to discipline effectively with tolerance and patience, understanding how to talk with and listen to their children to give them confidence, identifying ways to answer their children's questions, learning to make decisions together with their children and to give them advice, and learning to share emotions with their children.

Second, the women talked about a sense empowerment from learning how to help their children be successful in school. They talked about learning to read to their children by using the bilingual books that are given to the children at every meeting; discovering ways to make learning fun rather than boring; understanding the importance of providing educational books, games, and toys; understanding the importance of maintaining contact with their children's teachers; finding ways of having time to do homework and time to watch TV; and learning to maintain a relationship of teacher-parent.

Third, the women told of observed differences in their children's attitudes toward and performance in school. They described their children's relief at being in a program (the Family Literacy Program) where the other children looked like them and spoke both English and Spanish. They noticed improvements in their children's grades.

Lastly, over the course of the study, I observed differences in women's attitudes toward the program. There was a significantly increased number of suggestions about the program in terms of the running of the program regarding meeting times, meals, etc. They enacted increased ownership of the content of the program by asking for literacy activities and deeper learning experiences for themselves and their children.

However, the data also provided evidence of the dissonances that occurred with the implementation of the Auralog program. These disconnects occurred due to several reasons. First, some of the women were unable to participate in Auralog. Although grant funding provided the computers, the training, and the online program, there was no funding for the initial internet hook-up or monthly fees, causing the program to be prohibitively expensive for some of the women. In addition, work schedules caused some of the women to have difficulty in doing the required five hours of work on Auralog per week.

Consequently, the lack of participation in Auralog resulted in a lack of interest in the Family Literacy Program. Frustrations arose due to computer problems, both technical and skill related. Tensions grew between the women who were able to use the computer and those who couldn't for whatever reason. The women also expressed boredom with the repetitive nature of the activities and exercises.

In summary, the mothers described the program as providing meaningful parenting education, attitudinal changes regarding education, and an environment that fosters improved self esteem and school performance in their children. Nonetheless, they expressed discontent with the Auralog program and a desire to discontinue their participation in that aspect of the Family Literacy Program.

\section{Educational Importance of the Study}

This paper is intended as a contribution to the larger issue of developing alternative ways of helping Latino children to be successful in school. By examining a program that is situated in a university service-learning class, it is also possible to explore the reciprocal benefits to teacher candidates who can deepen their understanding of diversity by participating in a family literacy program in which parents are partners. Finally, the study suggests that family literacy programs need to be collaborative in planning and implementation.

The resultant findings suggest that a program involving parents as collaborators in their children's education enables the parents to become empowered as partners in their children's education. The findings also indicate that parents who become engaged in their children's education develop a better understanding of public school expectations. Lastly a program that stresses reading and creative play with children helps parents to appreciate the importance of educational play and interaction with children.

Further research is indicated for the program to investigate the impact of biliteracy on the women and in turn on the children. I am also interested in delving more deeply into the women's stories of literacy in their heritage language. Lastly, I would like to investigate the literacy that is present in their lives at this point. Despite the dissonances that have occurred as a result of the women's participation in Auralog, the women who have participated in the online language program have generally liked the program and plan to continue with it. The women who have computers describe them as "abriéndome el mundo" (opening the world to me).

\section{References}

Anderson, J. (1999). Service-learning and teacher education. URL http://www.ercidigests.org/1999-1/service.html.

August, D., \& Shanahan, T. (Eds.) (2006). Report of the national literacy panel on language minority youth and children. Mahwah, NJ: Lawrence Erlbaum Associates.

Cochran-Smith, M. (1999). Learning to teach for social justice. In G. A. Griffith (Ed.), The education of teachers: Ninety-eighth yearbook of the national society for the study of education (pp. 114-144). Chicago: University of Chicago.

Dewey, J. (1997). My pedagogic creed. In D. J. Flinders, \& S. J. Thornton (Eds.), The curriculum studies reader (pp. 17-23). New York, NY: Routledge.

Freire, P. (1970). Pedagogy of the oppressed. New York, NY: Continuum Publishing.

Freire, Paulo, \& Macedo, D. (1987). Literacy: Reading the word and the world. South Hadley, MA: Bergin and Garvey.

Gadsden, V. (2004). Designing and conducting family literacy programs that account for racial, ethnic, religious, and other cultural differences. URL

http://www.ed.gov/pubs/FamLit/design.html.

Gonzalez, N. E., Moll, L., \& Amanti, C. (Eds.) (2005). Funds of knowledge: Theorizing practices in households, communities, and 
classrooms. Mahwah, NJ: Lawrence Erlbaum Associates.

Grant, R. A., \& Wong, S. D. (2003). Barriers to literacy for languageminority learners: An argument for change in the education profession. Journal of Adolescent and Adult Literacy, 46, 386-394. doi:10.1598/JAAL.46.5.2

Greenberg, J., \& Moll, L. C. (1990). Creating zones of possibilities: Combining social contexts for instruction. In L. C. Moll (Ed.), Vygotsky and education: Instructional implications and applications of sociohistorical psychology (pp. 319-348). Cambridge: Cambridge University.

Heaney, T. (1996). Adult education for social change: From center stage to the wings and back again. URL

http://www.nl.edu/academics/cas/ace/resources/TomHeaney_Insight. $\mathrm{cfm}$

Jasis, P., \& Jasis-Ordóñes, R. (2004) Convivencia to empowerment: Latino parent organizing at la familia. The High School Journal, 88, 32-42. doi:10.1353/hsj.2004.0023

Krashen, S. (1997). The comprehension hypothesis: Recent evidence. English Teachers' Journal (Israel), 51, 17-29.

Merriam, S. B. (1998). Qualitative research and case study applications in education (2nd ed.). San Francisco: Jossey-Bass.

Nieto, S. (1999). The light in their eyes: Creating multicultural learning communities. NY: Teachers College Press: Multicultural Education
Series.

Pierce, M. S., \& Brisk, M. E. (2002). Sharing the bilingual journey: Situational autobiography in a family literacy context. Bilingual Research Journal, 26, 575-597.

doi:10.1080/15235882.2002.10162579

Smylie, M. A., Bay, M., \& Tozer, S. E. (1999). Preparing teachers as agents of change. In G. A. Griffith (Ed.), The education of teachers: Ninety-eighth yearbook of the national society for the study of education (pp. 18-62). Chicago: University of Chicago.

Tilley-Lubbs, G. A. (2007). The intersection of the academy and the community: Researching relationships through community-based education. In A. Wurr, \& J. Hellebrandt, (Eds.) Learning the language of global citizenship: Service-learning in applied linguistics. Bolton, MA: Anker.

Ward, J. V. (1997). Encouraging cultural competence in service-learning practice. In J. Schine (Ed.) Service-learning: Ninety-sixth Yearbook for the Society for the Study of Education, Part I (pp. 136-148). Chicago: University of Chicago.

Wood, W. J. (1998). Santa Clara University's Eastside Project: A pilgrimage toward our own humanity. In E. Zlotkowski (Ed.), Successful service-learning programs: New models of excellence in higher education (pp. 189-209). Bolton, MA: Anker. 